\title{
Views of pharmacists on involvement in ward rounds in selected public hospitals in Limpopo Province
}

\author{
Authors: \\ Ditonkana A. Sello ${ }^{1}$ \\ Yoswa M. Dambisya ${ }^{1}$ \\ Affiliations: \\ ${ }^{1}$ Department of Pharmacy, \\ School of Health Sciences, \\ University of Limpopo, South \\ Africa \\ Correspondence to: \\ Ditonkana Sello \\ Email: \\ abram.sello@ul.ac.za \\ Postal address: \\ Private Bag X1106, Sovenga \\ 0727, South Africa \\ Dates: \\ Received: 13 Apr. 2013 \\ Accepted: 19 June 2014 \\ Published: 19 Sept. 2014 \\ How to cite this article: \\ Sello, D.A. \& Dambisya, \\ Y.M., 2014, 'Views of \\ pharmacists on involvement \\ in ward rounds in selected \\ public hospitals in Limpopo \\ Province', Health SA \\ Gesondheid 19(1), Art. \#740, \\ 7 pages. http://dx.doi. \\ org/10.4102/hsag.v19i1.740

\section{Copyright:} \\ (C) 2014. The Authors. \\ Licensee: AOSIS \\ OpenJournals. This work \\ is licensed under the \\ Creative Commons \\ Attribution License.
}

Background: Pharmacist participation in ward rounds is of increasing interest for better pharmaceutical care, yet most pharmacists do not engage in this activity.

Objective: The objective was to obtain public sector pharmacists' views and perceptions on their involvement in ward rounds.

Method: A rapid assessment was conducted using a semi-structured questionnaire sent to five hospitals in Limpopo Province.

Results: There were 55 respondents (61.8\% female), mainly from the Polokwane-Mankweng Hospital Complex (69.1\%); 45 (82\%) were young pharmacists aged 25 to 34, whilst experience varied from $0 \leq 5$ years $(69.1 \%), 5 \leq 10$ years $(16.4 \%)$ to $>10$ years $(14.5 \%)$. The respondents included interns $(n=21)$, community service pharmacists $(n=7)$ and junior pharmacists $(n=8)$. Most had trained at University of Limpopo $(n=49)$, with a few from North-West University $(n=4)$, Wits $(n=1)$ and Durban-Westville $(n=1)$. The majority $(94.5 \%)$ felt that it was necessary for pharmacists to be involved in ward rounds. Twenty-seven respondents $(49.1 \%)$ said that pharmacists were involved in ward rounds and 21 of these $(77.8 \%)$ said ward visits were to check on drug stocks, but not for direct patient care. Proposals to prepare pharmacists better for ward rounds included pre-service training (34.9\%), internship (37.2\%), community service $(4.7 \%)$, post-graduate courses $(8.1 \%)$ and continuing professional development (15.1\%).

Conclusion: Pharmacists in the public hospitals studied in Limpopo were willing to be involved in clinical ward rounds and suggested that this be introduced during undergraduate training. These findings support the plans for the Turfloop BPharm programme to introduce clinical ward rounds.

Agtergrond: Die teenwoordigheid van aptekers tydens saalrondtes is van toenemende belang vir beter farmaseutiese sorg, maar baie aptekers is nie betrokke by by hierdie aktiwiteit nie.

Doelstelling: Die doel van die studie was om die menings en persepsies van aptekers in die openbare sektor te verkry oor hulle betrokkenheid by saalrondtes.

Metode: 'n Vinnige assessering was gedoen met behulp van 'n semi-gestruktureerde vraelys wat na vyf hospitale in Limpopo gestuur is.

Resultate: Daar het 55 respondente aan die studie deelgeneem (61.8\% vroue). Die meerderheid was van die Polokwane-Mankweng hospitaalkompleks (69.1\%). Daar was 45 (82\%) jong aptekers tussen die ouderdomme van 25 en 34, terwyl ervaring gewissel het van 0 tot 5 jaar $(69.1 \%), 6$ tot 10 jaar $(16.4 \%)$, tot 10 jaar of meer $(14.5 \%)$. Die respondente het die volgende ingesluit: interns $(n=21)$, gemeenskapsdiensaptekers $(n=7)$ en junior aptekers $(n=8)$. Die meeste het hul tersiêre opleiding aan die Universiteit van Limpopo verkry $(n=49)$, met 'n paar van die Noord-Wes Universiteit $(n=4)$, Wits $(n=1)$ en DurbanWestville $(n=1)$. Die meerderheid $(94.5 \%)$ het gevoel dat dit wel nodig is vir aptekers om in saalrondtes betrokke te wees. ' $n$ Totaal van 27 respondente $(49.1 \%)$ het aangedui dat aptekers betrokke is by saalrondtes, maar 21 uit die 27 (77.8\%) het saalbesoek omskryf as die nagaan van saalvoorraad en nie direkte pasiëntesorg nie. Voorstelle om aptekers beter voor te berei vir saalrondtes het die volgende ingesluit: pre-diens opleiding (34.9\%), internskap (37.2\%), gemeenskapsdiens $(4.7 \%)$, nagraadse kursusse $(8.1 \%)$, en deur middel van voortgesette professionele ontwikkeling (15.1\%).

Gevolgtrekkings: Aptekers in die openbare hospitale bestudeer in Limpopo was bereid om in die kliniese saalrondtes betrokke te wees en het voorgestel dat dit tydens voorgraadse opleiding ingestel word. Hierdie bevindings ondersteun die planne vir die Turfloop BPharm program om kliniese saalrondtes in te stel. 


\section{Introduction}

The pharmacy profession and the practice of pharmacy have evolved over the years and, at present, the pharmacist is expected to play a vital role in the care and management of the patient in all settings (Fertleman, Barnett \& Patel 2005; Ni et al. 2008). Thus, the field of clinical pharmacy has come of age as a pharmacy specialty in order to bridge the gap between the pharmacist as a custodian of medicine and the clinical (ward-based) health professionals, such as nurses and physicians. The practice of clinical pharmacy enables pharmacists to participate as part of the team at the interface with the patient and allows them to influence clinical care decisions to the benefit of the patient through proper pharmaceutical care. Hospital ward rounds are one way to ensure quality pharmaceutical care, where therapeutic stakeholders work together to improve aspects such as quality assurance, safety, effective administration of medicines, promotion of the rational use of medicines, public education and the monitoring of adverse drug effects (Jungnickel et al. 2009; Reeves \& Lewin 2004). It has been shown in various settings that such ward rounds improve patient-provider communication, with better patient outcomes and more cost-effective expenditure on pharmaceutical products. For instance, the presence of a pharmacist on a post-take ward round was shown to improve the accuracy of drug history documentation, reduce prescribing costs and decrease the potential risk to patients in hospital (Fertleman et al. 2005; Lewin \& Reeves 2011).

Traditionally, the pharmacist has undertaken a number of roles on the wards, such as the management of pharmaceutical stock and the provision of information on drug use and storage but with less involvement in actual patient care decisions and pharmaceutical care (Fertleman et al. 2005). It is thought that greater involvement of pharmacists in ward rounds helps reduce problems such as prescribing errors (Dean et al. 2002; Fertleman et al. 2005; Franklin et al. 2011). There have been many changes to the training and practice of pharmacy worldwide since the 1960s, including the introduction of clinical pharmacy training as a specialty in the profession (Dooley et al. 2004; Society of Hospital Pharmacists of Australia [SHPA] 2005).

There is thus increasing demand for pharmacist expertise in the care of patients; the concept of pharmaceutical care requires that pharmacists be well versed in the actual care of patients, beyond their primary role as custodians of pharmaceutical products. However, the training of pharmacists has hitherto been without much emphasis on pharmacist involvement in patient care and the shortage of clinical pharmacists further compounds the gap in pharmacist expertise at the coalface (Dean et al. 2002). It is not clear to what extent current hospital pharmacists are involved in ward rounds, or how they would view moves to introduce ward round-related activities for pharmacists in public hospitals in the Limpopo Province. In an attempt to keep abreast of developments in that regard, the University of Limpopo (Turfloop Campus) undertook several curriculum review exercises, including the greater involvement of the Bachelor of Pharmacy (BPharm) students in clinical and experiential learning activities. One avenue for the extended involvement in clinical activities is the ward round, of which the present study was a rapid assessment of the status quo.

\section{Aims of the study}

The aim of the study was to gauge the views of pharmacists in public sector hospitals in the Limpopo Province on pharmacists' involvement in ward rounds. The objectives of the present study were to:

- Determine the extent to which pharmacists in selected hospitals in the Limpopo Province were involved in ward rounds.

- Obtain the views of the pharmacists on their possible role in ward rounds and pharmaceutical care in selected hospitals in the Limpopo Province.

- Establish what, in the view of pharmacists in the selected hospitals, should be done in order to facilitate/ strengthen/improve pharmacist involvement in ward rounds.

- Gauge the perceptions of pharmacists in the selected hospitals regarding enabling factors and barriers to pharmacist involvement in ward rounds.

\section{Significance of the study}

There is a need for the introduction of clinical pharmacy practice and training in the hospitals through involvement of pharmacists in ward rounds and to strengthen their intervention through pharmaceutical care. The present study contributes to bridging the knowledge gap on the aspects of clinical pharmacy practice in the hospital and therefore helps guide efforts toward improvements in the training of pharmacy students in the clinical areas. It may also contribute to the development of the scope of practice for the clinical pharmacist in South Africa.

\section{Research method and design Design}

This was a descriptive, cross-sectional study using a semistructured, self-administered questionnaire targeted at pharmacists in public hospitals in the Limpopo Province. The questionnaire was sent to all pharmacists, irrespective of level or experience. This study design was chosen in order to provide a snapshot of the views from pharmacists across a range of facilities within a short time, at relatively low cost and without disrupting service delivery.

\section{Context of the study}

The study was conducted in the Limpopo Province, with a focus on public sector hospitals that are used as training 
sites for BPharm students from the Turfloop Campus of the University of Limpopo.

\section{The study site}

The study was conducted in the Polokwane-Mankweng Hospital Complex (which has two hospital campuses Polokwane and Mankweng) and in Mokopane, St. Rita's and Seshego hospitals. These facilities are all used, to various extents, for the clinical and experiential learning of BPharm students from the Pharmacy Programme at the Turfloop Campus of the University of Limpopo.

\section{Study population and sample}

At the time of the study, the five hospitals included in the study had a total population of 95 pharmacists - 31 at Polokwane, 29 at Mankweng, 15 at Mokopane, 11 at St. Rita's and 9 at Seshego. Before starting data collection, we received advice from the statistician to the effect that a number of respondents greater than 48 would provide the study with adequate power. This was based on a modified Krejcie and Morgan (1970) calculation, taking into account the fact that not all pharmacists would be available and accessible at their stations at all times. The fact that the study included qualitative aspects made the sample size determination less stringent. Nevertheless, attempts were made to contact all the pharmacists in the five hospitals. Because of the complexity of the work schedules at the different facilities, it was only possible to have 59 of the 95 pharmacists (62\%) complete the questionnaire during the rapid assessment period.

\section{Inclusion and exclusion criteria}

All pharmacists attached to the five hospitals who were present and available to participate in the study were included. We excluded all those pharmacists who were on leave or on outreach services at the time of the study.

\section{Data collection methods}

A 22-item semi-structured self-administered questionnaire with both open-ended and closed questions was designed for the study. It was pre-tested for clarity and relevance of the questions on registered pharmacists working in the Department of Pharmacy at the University of Limpopo, Turfloop Campus $(n=4)$ and final-year B Pharm students $(n=10)$ prior to finalisation and use in the selected hospitals.

The questionnaire was delivered to the hospital after prior contact with the relevant authorities. The pharmacy manager (or his delegate) assisted in identifying which pharmacists were available to complete the questionnaire and in ensuring in all cases that this was not at the expense of service delivery. The questionnaire took between 15 and 25 minutes to complete, typically being done during the pharmacist's break.

\section{Data analysis}

Data were captured onto a Microsoft ${ }^{\circledR}$ Excel spreadsheet from which summary statistics were generated for the responses to the major questions, and subsequent statistical analysis was done using SPSS version 21.0 (IBM, Armonk, NY, 2012). Responses from the open-ended questions were grouped according to common categories generated after a preliminary scan of a random sample $(n=6)$ of the completed questionnaires. The two investigators analysed the openended responses and assigned categories separately, after which these were discussed and consensus reached on the most appropriate one in case of any discrepancy. The kappa statistic was not calculated as there was unanimity on the categories between the researchers. The frequency of the common categories was then calculated.

The results are presented as descriptive summary statistics, whilst associations between variables such as gender, age, level of appointment and experience, on the one hand, as well as views on pharmacist involvement in ward rounds, on the other, were tested using contingency tables and the Chisquare test, with $p<0.05$ as the limit of significance.

\section{Ethical considerations}

This was one of the activities in the quality improvement plan for the Department of Pharmacy, University of Limpopo, Turfloop Campus and was not considered to be a study requiring ethical clearance, provided that the relevant authorities (province and facility level) had no objections to the rapid assessment being undertaken. All the respondents were briefed on the aim of the rapid assessment and were informed that completing the questionnaire would be taken as their consent for their views to be included in the final analysis. In all cases, the questionnaires were completed anonymously and no views could be traced back to the individual respondent.

\section{Validity and reliability}

The study employed a sample size that was more than $60 \%$ of the target in order to minimise bias and to improve the application of the findings to a broader population. Bias was further minimised by the fact that the respondents completed the questionnaires free of interference from the investigators or the hospital authorities; moreover, they were not required to identify themselves. The study tool was validated and pre-tested prior to being finalised and used in the survey. The independent analysis of the open-ended questions by each investigator also reduced the possibility of bias, notwithstanding the fact that in the end there were no discrepancies between the categories derived by the two investigators.

\section{Results}

\section{The respondents}

There were 55 respondents $(57.8 \%$ response rate), mainly from Polokwane Hospital $(n=22 ; 40 \%)$ and Mankweng Hospital ( $n=16 ; 29 \%)$, as is shown in Table 1 . Most of the respondents were female $(61.8 \% ; n=34)$, whilst $38.2 \%(n=21)$ 
were male. The age distribution of the respondents is shown in Table 2; the majority $(n=45 ; 82 \%)$ of the respondents were young pharmacists aged 34 years or younger.

The respondents' experience varied from less than five years to 10 years or more, as is shown in Figure 1.

By level of appointment, the intern respondents ranged from interns to chief pharmacist, as is shown in Table 3. Three respondents did not indicate their level of appointment.

The respondents' undergraduate training was completed at the University of Limpopo $(n=49 ; 89.1 \%)$, North-West University, Potchefstroom $(n=4 ; 7.3 \%)$, the University of the Witwatersrand $(n=1 ; 1.8 \%)$ and the University of DurbanWestville $(n=1 ; 1.8 \%)$.

TABLE 1: Respondents by facility.

\begin{tabular}{lcc}
\hline Hospital & \multicolumn{2}{c}{ Respondents } \\
\cline { 2 - 3 } & Number $(\boldsymbol{n})$ & \% of total \\
\hline Polokwane & 22 & 40 \\
Mankweng & 16 & 29 \\
Seshego & 8 & 15 \\
Mokopane & 5 & 9 \\
St Rita's & 4 & 7 \\
\hline
\end{tabular}

TABLE 2: Age distribution of the respondents.

\begin{tabular}{ll}
\hline Age range & Number $(\%)$ \\
\hline$<25$ years & $12(21.8)$ \\
$25-34$ years & $33(60)$ \\
$35-44$ years & $6(10.9)$ \\
$45-54$ years & $3(5.5)$ \\
$55+$ years & $1(1.8)$ \\
\hline
\end{tabular}

TABLE 3: Level of appointment of the respondents.

\begin{tabular}{ll}
\hline Level of appointment & $\begin{array}{l}\text { Number of respondents } \\
\text { (\% of total) }\end{array}$ \\
\hline Interns & $21(38.2)$ \\
Community service pharmacists & $7(12.7)$ \\
Junior pharmacists & $8(14.5)$ \\
Senior pharmacists & $7(12.7)$ \\
Principal pharmacists & $8(14.5)$ \\
Chief pharmacist & $1(1.8)$ \\
No response & $3(5.5)$ \\
\hline
\end{tabular}

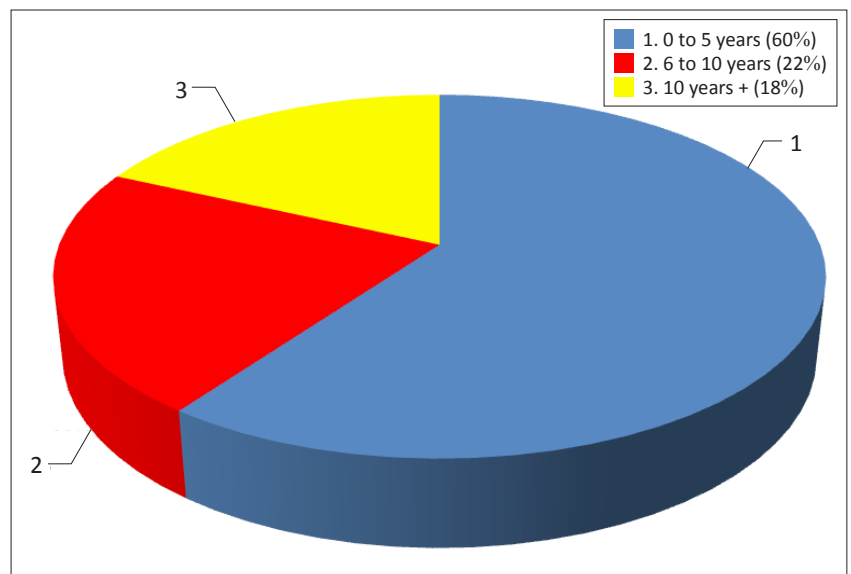

FIGURE 1: Respondents' years of experience.

\section{The hospitals}

All hospitals surveyed had Drug and Therapeutics Committees (DTC). A total of $13(23.6 \%)$ of the respondents were members of a DTC - these respondents tended to be the older, more experienced pharmacists. According to those who were members of a DTC, the committees met once a month in each hospital and discussed a wide range of issues, including patient cases, prescribing patterns and errors, ideas for improvement, availability of drugs, rational prescribing and dispensing, handling of expired medicines and monitoring and evaluation of antibiotic use.

\section{Are pharmacists involved in ward rounds at your hospital?}

Twenty-seven (27) respondents (49.1\%) indicated that they were involved in ward rounds, whilst 28 (50.9\%) stated that they were not. For the question regarding their involvement, the most frequent answers were: (1) checking on patient use of medicines; (2) checking the ward stock and the schedule 5 and schedule 6 registers; and (3) checking on storage and management of medicines by nurses. Those who reported being involved in ward rounds stated that such activities did not involve interaction with doctors. Only eight respondents $(14.5 \%)$ indicated that they had participated in ward rounds as pharmacy students and all of these had graduated from the University of Limpopo. The eight who reportedly participated in ward rounds whilst still students fell across all levels of pharmacy three interns, one community pharmacist, two principal pharmacists, one senior pharmacist and one chief pharmacist.

\section{Should pharmacists be involved in ward rounds?}

Regarding whether pharmacists should be involved in ward rounds, 52 respondents (94.5\%) stated that there was a need, one stated that there was no need and two did not reply.

The reasons advanced for pharmacists being involved centred around ensuring better utilisation of drugs on the ward through interaction with doctors and support for nurses; better management of pharmaceutical stocks on the wards in order to avoid expiry of ward stock; minimising prescribing errors by doctors through consultation; better patient counselling before the patients are discharged; providing a pharmacist's perspective on patient problems through proper clinical pharmacy assessment; and being ready to address any drug-related questions from other health professionals. The distribution of the responses is summarised in Table 4.

There was a contrary view to the effect that pharmacists were already over-burdened and, since they were always available for consultation by other professionals if needed, they should concentrate on their existing responsibilities without also taking on ward-related activities. 


\section{How should pharmacist involvement in ward rounds be introduced?}

Suggestions were received regarding how pharmacist involvement in ward rounds should be introduced, from 52 respondents (94.5\%) in favour of pharmacist involvement in ward rounds. One of the most popular suggestions (made by 32 of the 52 respondents; 62\%) was that it should be through consultation with major stakeholders, such as hospital management, pharmacy staff, pharmacists and other health professionals, especially the doctors and nurses. It was also suggested that pharmacists should be educated regarding the importance of ward rounds and that clear, written programmes and guidelines should be developed as part of standard operating procedures for hospital pharmacy departments. Other suggestions were that this should be promoted through the DTC $(n=17 ; 32.7 \%)$ or that the decision be taken at high-level policy forums, making ward rounds one of the performance areas for a pharmacist's job description ( $n=11 ; 21.2 \%$ ). In terms of process, it was the view that, once the decision was agreed upon, pharmacists should be assigned to specific wards on rotational basis and it should be a continuing professional development (CPD) requirement for pharmacists in hospitals to participate in ward rounds. To be even more effective, a number of respondents $(n=8 ; 15.4 \%)$ suggested that ward rounds should be included at the undergraduate level and that inservice programmes should be held for pharmacists already in practice. The suggestions received are summarised in Table 5 .

On whether there was any resistance anticipated, the majority of respondents $(n=51 ; 92.7 \%)$ did not envisage any resistance. Amongst those who expected some level of resistance $(n=4 ; 7.3 \%)$, the sources of resistance were named as doctors, those pharmacists not interested in work/hardcore clinical work, pharmacists who already felt overworked, nurses who were thought to view the ward as their turf and hospital management, especially chief executive officers with a medical background.

\section{Discussion}

Most of the respondents were supportive of pharmacist involvement in ward rounds; the hospitals surveyed did not involve pharmacists in ward rounds except for pharmaceutical product management such as ward stock

TABLE 4: Why pharmacists should be involved in ward rounds.

\begin{tabular}{ll}
\hline Suggested Reason(s) & $\begin{array}{l}\text { Number of responses } \\
\text { (\% of total responses) }\end{array}$ \\
\hline Ensure better utilisation of drugs on the wards & $38(24.8)$ \\
Better management of pharmaceutical stock on the wards & $32(20.9)$ \\
Minimise prescription errors & $28(18.3)$ \\
$\begin{array}{l}\text { Better patient counselling on discharge } \\
\text { Better pharmacist understanding of patient perspectives }\end{array}$ & $14(14.4)$ \\
$\begin{array}{l}\text { Address drug-related questions from other health } \\
\text { professionals }\end{array}$ & $14(9.2)$ \\
$\begin{array}{l}\text { Offer other pharmacy-related support to other health team } \\
\text { members }\end{array}$ & $5(3.2)$ \\
\hline
\end{tabular}

$\dagger$, Respondents could give more than one answer. inventory. All hospitals surveyed, however, involve pharmacists in clinical decisions through the DTC which meets monthly. Very few of the respondents were involved in ward rounds as pharmacy students and most of them are of the view that pharmacists' involvement in ward rounds should be introduced during the undergraduate course.

The favourable views of the pharmacists surveyed are in consonance with the intentions of the South African Pharmacy Council (SAPC) to strengthen and recognise clinical pharmacy as a specialty (SAPC 2011). The pharmacists are eager to contribute to improving the quality of healthcare for the benefit of the patient through, for instance, improved medication management of patients, reduction or prevention of medication errors and identification and management of adverse drug reaction in a timely manner. The presence of clinical pharmacists at the hospitals will facilitate the involvement of other pharmacists in greater patientrelated care, with benefits such as better patient-provider communication, better patient outcomes and more costeffective expenditure on pharmaceutical products such as drugs (Reeves \& Lewin 2004; Wakefield et al. 2010). The clinical pharmacists will also strengthen the training of future pharmacists by supporting and supervising the students during the ward round rotations (Brazeau et al. 2009). The initiative by the University of Limpopo to undertake this assessment was timely as it found that pharmacists are ready for the kind of change that the University seeks to introduce.

However, care should be taken to introduce the pharmacist's involvement in ward rounds gradually; preferably through a consultative process that will not alienate any of the stakeholders and that will not be seen as increasing the already overloaded pharmacists with extra work (Reeves \& Lewin 2004). The findings showed a lack of understanding and different views regarding what ward round involvement or participation by the pharmacists should entail. Clearly, the concept of pharmaceutical care is not yet implemented in these public hospitals, despite their being academic institutions and the biggest referral hospital of the province. That is consistent with findings from elsewhere about the confusion regarding ward round practice - for instance, Price states that little is known about the ward rounds practice amongst both professionals and patients (Price 2005), echoing views of other authors (Hodgson, Jamal \& Gayathri 2005; White \&

TABLE 5: How pharmacist involvement in ward rounds should be introduced.

\begin{tabular}{|c|c|}
\hline Approach suggested & $\begin{array}{l}\text { Number of respondents } \uparrow \\
\text { (\% of respondents) }\end{array}$ \\
\hline Consultation with major stakeholders & $32(61.5)$ \\
\hline $\begin{array}{l}\text { Educate pharmacists on importance of ward rounds } \\
\text { (including CPD activities) }\end{array}$ & $15(28.8)$ \\
\hline Develop clear programme and guidelines & $13(25.0)$ \\
\hline Promote through DTC & $17(32.7)$ \\
\hline $\begin{array}{l}\text { High-level decision to include ward rounds in pharmacist } \\
\text { job description }\end{array}$ & $11(21.2)$ \\
\hline Introduce ward rounds at undergraduate level & $8(15.4)$ \\
\hline Assign pharmacists specific wards on rotational basis & $3(5.8)$ \\
\hline
\end{tabular}


Karim 2005). Similarly, the 'scope' of pharmacist involvement needs to be worked out carefully and communicated to the pharmacists and other health professionals, especially the doctors and nurses with whom the pharmacists will interact on the wards (Dooley et al. 2004). The joint effort of clinical pharmacists, educational institutions and the SAPC will be required in order to ensure the smooth introduction of these activities through CPD activities. The establishment of model hospitals with pharmacist involvement in ward rounds would be another positive step - those would then serve to show how the idea can work in reality.

Change is always associated with some form of resistance the status quo offers a comfort zone that many are not willing to trade in for innovation. The majority of respondents in the present study do not expect any resistance; perhaps based on their experience within the facilities where they see an obvious need for pharmacist intervention in the care of patients in the wards. Nevertheless, possible obstacles, such as inflexible attitudes, should be borne in mind.

Most of the respondents in the five hospitals were graduates of the University of Turfloop Pharmacy Programme $(n=49$; $90.1 \%$ ), showing that most of the hospital pharmacies in Limpopo Province are staffed by graduates from Turfloop. It has been reported previously that graduates from the Turfloop Pharmacy Programme are more likely to be retained within the Limpopo Province and are more likely to work in the public sector than their counterparts from other schools in South Africa (Dambisya, Modipa \& Legodi 2007). It would appear that this trend continues, which would support the World Health Organization's recommendation for the location of training institutions in areas of great human resources for health scarcity (Dolea, Stormont \& Braichet 2010). The Limpopo Province has some of the lowest densities of skilled health professionals in the public sector and the high retention of graduates from schools located in the province should thus be exploited in order to strengthen the capacity of those schools to train even more health professionals. In this context, improvements in the training programme for pharmacists at Turfloop would translate into better-quality pharmacy services in the Limpopo Province.

The primary objective for the assessment was to establish the views of the hospital pharmacists on the issue of pharmacist involvement in ward rounds and, ultimately, to understand what it would take to get pharmacy students involved in ward rounds. On both counts we found answers - that the pharmacists like the idea, that they would like to be involved and that most of them have not been involved in ward rounds; even those who indicated that they were involved have only been involved in the context of ward stock management and not for patient clinical care. There was also the overwhelming view that this should be introduced during the undergraduate course - which fits in with the thinking from the University. The next logical steps, then, are for the University team to suggest possible approaches for consideration by their colleagues in the hospitals, after which the experiential learning manuals for the pharmacy students will be revised and updated to include time for ward rounds. The inclination is to suggest that, in the spirit of inter-professional education, this could be done in the interim under the supervision of the doctors and nurses on the wards, with the pharmacy students joining medical and nursing students during the teaching ward rounds. That will have the added advantage of having the students trained in a team, which should then make it easier for them to function in a health team after graduation (Bond, Raehl \& Franke 2002).

\section{Limitations of the study}

The study was confined to five hospitals of the Limpopo Province, so the findings may not be applicable to all hospitals in the Province and to other parts of South Africa. It is possible that the picture is different in other parts of the country which offer more opportunities, including clinical pharmacy, for pharmacists. The study was also confined to public sector facilities, so the findings cannot be extrapolated to the private sector hospitals which tend to be better staffed (SAPC 2011). The use of a structured questionnaire did not allow for the probing of the reasons behind the responses provided. A more in-depth study, covering a wider selection of hospitals, may be required in order to establish more fully the situation in the rest of the province.

\section{Recommendations}

Notwithstanding the above limitations, the findings from the present study support the recommendations for the strengthening and/or establishment of clinical pharmacy training toward a specialty course, the greater involvement of pharmacists in clinical ward rounds and the introduction of clinical pharmacy ward rounds during BPharm training at the undergraduate level.

\section{Conclusion}

There is presently no pharmacist involvement in ward round clinical patient care in the selected hospitals in the Limpopo Province. The pharmacists are in support of the initiative, are willing to be involved and suggest that future pharmacists be introduced to ward rounds during the undergraduate course, whilst at the hospitals this should be done through a consultative and participatory process. These findings support the plans for the Turfloop BPharm programme to introduce clinical ward rounds.

\section{Acknowledgements}

The authors would like to thank their colleagues in the Dept of Pharmacy, Turfloop Campus, for their help in questionnaire development, the 10 final-year students on whom the questionnaire was pre-tested and the hospital pharmacists who completed the questionnaire. The assistance of the Pharmacy Managers in the hospitals is also acknowledged. The survey arose from an action point in the Department Quality Improvement Plan and all colleagues 
who contributed to the vibrant discussions in this regard are thanked for their input.

\section{Competing interests}

The authors declare that they have no financial or personal relationship(s) which may have inappropriately influenced them in writing this article.

\section{Author contributions}

Both authors (University of Limpopo) contributed to the conceptualisation of the study, both conducted the survey and participated in the data analysis. D.A.S. drafted the article, whilst Y.M.D. provided critical revisions to the final manuscript before submission. Both authors agreed on the version of the manuscript that was submitted and the final revised and edited version.

\section{References}

Bond, C.A., Raehl, C.L. \& Franke, T., 2002, 'Clinical pharmacy services, hospital pharmacy staffing, and medication errors in United States hospitals', Pharmacotherapy 22(2), 134-147. http://dx.doi.org/10.1592/phco.22.3.134.33551

Brazeau, G.A., Meyer, S.M., Belsey, M., Bednarczyk, E.M., Bilic, S., Bullock, J. et al., 2009, 'Preparing pharmacy graduates for traditional and emerging career opportunities', American Journal of Pharmaceutical Education 73(8), 157. http:// dx.doi.org/10.5688/aj7308157

Dambisya, Y.M., Modipa, I.S. \& Legodi, M.G., 2007, 'Factors influencing the distribution of pharmacy graduates of the University of the North, South Africa', East African Medical Journal 84(10), 481-488.

Dean, B., Schachter, M., Vincent, C. \& Barber, N., 2002, 'Causes of prescribing errors in hospital inpatients: A prospective study', The Lancet 359(9315), 1373-1378. http://dx.doi.org/10.1016/S0140-6736(02)08350-2

Dolea, C., Stormont, L. \& Braichet, J.-M., 2010, 'Evaluated strategies to increase attraction and retention of health workers in remote and rural areas', Bulletin of the World Health Organization 88(5), 379-385. http://dx.doi.org/10.2471/BLT.09.070607
Dooley, M.J., Allen, K.M., Doecke, C.J., Galbraith, K.J., Taylor, G.R., Bright, J. et al., 2004 'A prospective multicentre study of pharmacist initiated changes to drug therapy and patient management in acute care government funded hospitals', British and patient management in acute care government funded hospitals', British j.1365-2125.2003.02029.x

Fertleman, M., Barnett, N. \& Patel, T., 2005, 'Improving medication management for patients: The effect of a pharmacist on post-admission ward rounds', Quality and Safety in Health Care 14(3), 207-211. http://dx.doi.org/10.1136/ qshc.2004.011759

Franklin, B.D., Reynolds, M., Shebl, N.A., Burnett, S. \& Jacklin, A., 2011, 'Prescribing errors in hospital inpatients: A three-centre study of their prevalence, types and causes', Postgraduate Medical Journal 87(1033), 739-745. http://dx.doi. org/10.1136/pgmj.2011.117879

Hodgson, R., Jamal, A. \& Gayathri, B., 2005, 'A survey of ward round practice', The Psychiatric Bulletin 29(5), 171-173. http://dx.doi.org/10.1192/pb.29.5.171

Jungnickel, P.W., Kelley, K.W., Hammer, D.P., Haines, S.T. \& Marlowe, K.F., 2009 'Addressing Competencies for the future in the Professional Curriculum', American Journal of Pharmaceutical Education 73(8), 156. http://dx.doi.org/10.5688/ aj7308156

Krejcie, R.V. \& Morgan, D.W., 1970, 'Determining sample size for research activities', Educational and Psychological Measurement 30, 607-610.

Lewin, S. \& Reeves, S., 2011, 'Enacting "team" and "teamwork": Using Goffman's theory of impression management to illuminate interprofessional practice on hospital wards', Social Science \& Medicine 72(10), 1595-1602. http://dx.doi. org/10.1016/j.socscimed.2011.03.037

$\mathrm{Ni}$, J-H., Song, X-J. \& Xie, X-J., 2008, 'Practice of ward round model of clinical pharmacists', China Pharmacy 2008-8.

Price, J., 2005, 'Wards rounds: For one or all?' The Psychiatric Bulletin 29, 353. http:// dx.doi.org/10.1192/pb.29.9.353-a

Reeves, S. \& Lewin, S., 2004, 'Interprofessional collaboration in the hospital: Strategies and meanings', Journal of Health Services Research \& Policy 9(4), 218-225. http:// dx.doi.org/10.1258/1355819042250140

Society of Hospital Pharmacists of Australia Committee of Specialty Practice in Clinical Pharmacy, 2005, 'SHPA standards of practice for clinical pharmacy', Journal of Pharmacy Practice and Research 35(2), 122-146.

South African Pharmacy Council (SAPC), 2011, Pharmacy human resources in South Africa, SAPC, Pretoria, South Africa

Wakefield, D.S., Ward, M.M., Loes, J.L., O'Brien, J. \& Sperry, L., 2010, 'Implementation of a telepharmacy service to provide round-the-clock medication order review by pharmacists', American Journal of Health-System Pharmacy 67(23), 2052-2057. http://dx.doi.org/10.2146/ajhp090643

White, R. \& Karim, B., 2005, 'Patients' views of the ward round: a survey', The Psychiatric Bulletin 29, 207-209. http://dx.doi.org/10.1192/pb.29.6.207 